\title{
Development of Novel 1,2,3,4-Tetrahydroquinoline Scaffolds as Potent NF- $\kappa$ B Inhibitors and Cytotoxic Agents
}

\author{
Hyeju Jo, ${ }^{\dagger}$ Minho Choi, ${ }^{\dagger}$ Arepalli Sateesh Kumar, ${ }^{\dagger}$ Yeongeun Jung, ${ }^{\dagger}$ Sangeun Kim, ${ }^{\dagger}$ \\ Jieun Yun, Jong-Soon Kang, ${ }^{*}$ Youngsoo Kim, ${ }^{\dagger}$ Sang-bae Han, ${ }^{\dagger}$ Jae-Kyung Jung, Jungsook Cho," \\ Kiho Lee, ${ }^{\S}$ Jae-Hwan Kwak, ${ }^{\perp}$ and Heesoon Lee*,† \\ ${ }^{\dagger}$ Department of Pharmacy, Chungbuk National University, Chungbuk 362-763, Republic of Korea \\ ${ }^{\ddagger}$ Korea Research Institute of Bioscience and Biotechnology, Ochang 363-883, Republic of Korea \\ ${ }^{\S}$ College of Pharmacy, Korea University, Sejong 339-700, Republic of Korea \\ "College of Pharmacy, Dongguk University, Goyang 410-773, Republic of Korea \\ ${ }^{\perp}$ College of Pharmacy, Kyungsung University, Busan 608-736, Republic of Korea
}

Supporting Information

ABSTRACT: 1,2,3,4-Tetrahydroquinolines have been identified as the most potent inhibitors of LPS-induced NF- $\kappa$ B transcriptional activity. To discover new molecules of this class with excellent activities, we designed and synthesized a series of novel derivatives of 1,2,3,4-tetrahydroquinolines $(\mathbf{4 a}-\mathbf{g}, \mathbf{5 a}-\mathbf{h}, \mathbf{6} \mathbf{a}-\mathbf{h}$, and $7 \mathbf{a}-\mathbf{h})$ and bioevaluated their in vitro activity against human cancer cell lines (NCI-H23, ACHN, MDA-MB-231, PC-3, NUGC-3, and HCT 15). Among all synthesized scaffolds, $6 \mathrm{~g}$ exhibited the most potent inhibition ( 53 times that of a reference compound) of LPS-induced NF- $\kappa \mathrm{B}$ transcriptional activity and the most potent cytotoxicity against all evaluated human cancer cell lines.

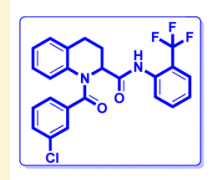

Inhibition of NF-KBactivity

Human Cancer Cell lines $\mathrm{NCl}-\mathrm{H} 23$ ACHN MDA-MB-231 $\mathrm{PC}-3$ NUGC-3 HCT 15

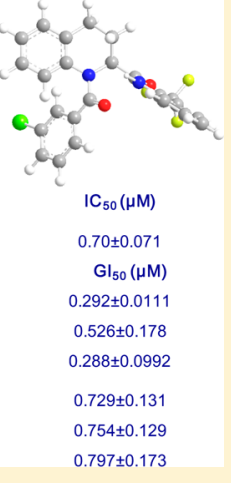

KEYWORDS: 1,2,3,4-Tetrahydroquinolines, NF- $\kappa B$ inactivation, in vitro cytotoxicity, human cancer cell lines

$\mathrm{NF}-\kappa \mathrm{B}$ is a lymphoid-specific protein that binds to the enhancer of kappa light chain in the nucleus of B cells; NF- $\kappa \mathrm{B}$ was discovered by Sen and Baltimore. ${ }^{1}$ NF- $\kappa$ B is involved in the regulation of many immune and inflammatory responses, cellular growth, and apoptosis. ${ }^{2,3}$ At present, NF- $\kappa$ B and its signaling is one of the most exciting and extensively studied research fields since NF- $\kappa \mathrm{B}$ dysregulation is associated with many diseases such as cancer, AIDS, asthma, arthritis, diabetes, and inflammatory bowel disease. ${ }^{4-6}$ Several natural and synthetic compounds, including some drugs, have been tested for their potential to inhibit NF- $\kappa \mathrm{B}$, but very few of them are suitable for anticancer therapy. ${ }^{7,8}$ Therefore, it has been suggested that the development of novel NF- $\kappa$ B inhibitors with antitumor and anti-inflammatory activities is most important. Our group has been involved in the development of novel potent NF- $\kappa \mathrm{B}$ inhibitors ${ }^{9-11}$ with anticancer activity.

Besides, quinolines and tetrahydroquinolines are important ubiquitous structural motifs in biologically active natural products and pharmacologically relevant therapeutic agents. $^{12-16}$ However, Khan et al. ${ }^{17}$ demonstrated that tetrahydroquinolines can be used as NF- $\kappa \mathrm{B}$ inhibitors as well as anti-HIV agents, anti-Parkinson's diseases, etc. María José Abad et al. ${ }^{18}$ also tested quinoline-based compounds as modulators of HIV transcription through NF- $\kappa \mathrm{B}$ and Sp1 inhibition. These distinct inhibitory activities have encouraged us to prepare such core motifs to test our hypothesis that their derivatives would act as most potent NF- $\kappa$ B inhibitors and have anticancer activity. We designed and synthesized different novel derivatives of 1,2,3,4-tetrahydroquinoline-2-carboxylic acid $N$-(substituted)phenyl amide and tested them as potential NF- $\kappa \mathrm{B}$ inhibitors and also evaluated their cytotoxicities against six human cancer cell lines (NCI-H23, ACHN, MDA-MB-231, PC-3, NUGC-3, and HCT-15). Based on our previous reports, $^{9-11}$ we wish to maintain amide functionality to the core motifs, and the effect of the synthesized molecules on $\mathrm{NF}-\kappa \mathrm{B}$ transcriptional activity was measured by using a reported procedure. ${ }^{19}$ In vitro cytotoxicity assay was performed using the number of cells measured indirectly by the sulforhodamine B method according to the National Cancer Institute (USA) protocol. $^{20}$

We commenced our synthesis from commercially available quinoline-2-carboxylic acid, which underwent amidation reaction with various substituted aromatic amines in the presence of the coupling reagent $1,1^{\prime}$-carbonyldiimidazole

Received: January 6, 2016

Accepted: February 16, 2016

Published: February 16, 2016 
Scheme 1. Synthesis of $3 a-g$ and $4 a-g$ Series of Scaffolds ${ }^{a}$<smiles>[R]c1cc(N)c([R])c([R])c1[R]</smiles><smiles>[R]c1cc(NC(=O)c2ccc3ccc4ccccc4nc2-3)c([R])c([R])c1[R]</smiles>

$R_{1}=R_{2}=R_{3}=R_{4}=H, 3 a, 80 \%$ $\mathrm{R}_{1}=\mathrm{OH} ; \mathrm{R}_{2}=\mathrm{R}_{3}=\mathrm{R}_{4}=\mathrm{H}, \mathbf{3 b}, \mathbf{5 7 \%}$ $\mathrm{R}_{3}=\mathrm{OH} ; \mathrm{R}_{1}=\mathrm{R}_{2}=\mathrm{R}_{4}=\mathrm{H}, \mathbf{3 c}, \mathbf{3 0} \%$ $\mathrm{R}_{3}=\mathrm{OCH}_{3} ; \mathrm{R}_{1}=\mathrm{R}_{2}=\mathrm{R}_{4}=\mathrm{H}, \mathbf{3 d}, \mathbf{6 3} \%$ $\mathrm{R}_{1}=\mathrm{CF}_{3} ; \mathrm{R}_{2}=\mathrm{R}_{3}=\mathrm{R}_{4}=\mathrm{H}, 3 \mathrm{3e}, \mathbf{4 9 \%}$ $\mathrm{R}_{3}=\mathrm{CF}_{3} ; \mathrm{R}_{1}=\mathrm{R}_{2}=\mathrm{R}_{4}=\mathrm{H}, \mathbf{3 f}, \mathbf{6 7 \%}$ $\mathrm{R}_{2}=\mathrm{R}_{4}=\mathrm{CF}_{3} ; \mathrm{R}_{1}=\mathrm{R}_{3}=\mathrm{H}, \mathbf{3 g}, \mathbf{4 6 \%}$
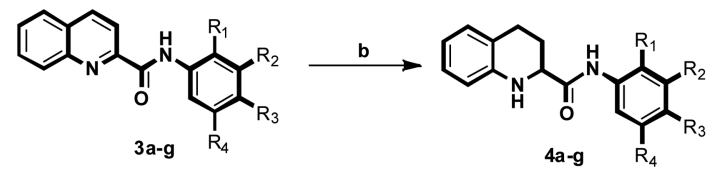

$\mathrm{R}_{1}=\mathrm{R}_{2}=\mathrm{R}_{3}=\mathrm{R}_{4}=\mathrm{H}, 4 \mathrm{a}, 49 \%$ $\mathrm{R}_{1}=\mathrm{OH} ; \mathrm{R}_{2}=\mathrm{R}_{3}=\mathrm{R}_{4}=\mathrm{H}, \mathbf{4 b}, \mathbf{3 6 \%}$ $\mathrm{R}_{3}=\mathrm{OH} ; \mathrm{R}_{1}=\mathrm{R}_{2}=\mathrm{R}_{4}=\mathrm{H}, \mathbf{4 c}, \mathbf{2 3} \%$ $\mathrm{R}_{3}=\mathrm{OCH}_{3} ; \mathrm{R}_{1}=\mathrm{R}_{2}=\mathrm{R}_{4}=\mathrm{H}, 4 \mathrm{~d}, 73 \%$ $\mathrm{R}_{1}=\mathrm{CF}_{3} ; \mathrm{R}_{2}=\mathrm{R}_{3}=\mathrm{R}_{4}=\mathrm{H}, \mathbf{4 e}, \mathbf{4 0 \%}$ $\mathrm{R}_{3}=\mathrm{CF}_{3} ; \mathrm{R}_{1}=\mathrm{R}_{2}=\mathrm{R}_{4}=\mathrm{H}, \mathbf{4 f}, \mathbf{1 0} \%$ $\mathrm{R}_{2}=\mathrm{R}_{4}=\mathrm{CF}_{3} ; \mathrm{R}_{1}=\mathrm{R}_{3}=\mathrm{H}, \mathbf{4 g}, \mathbf{3 5 \%}$

${ }^{a}$ Reagents and conditions: (a) CDI, anhydrous THF, RT, 1 h. (b) $\mathrm{Pd} / \mathrm{C}, \mathrm{H}_{2}$ balloon, EtOH, RT, $24 \mathrm{~h}$.

Scheme 2. Synthesis of $5 a-h, 6 a-h$, and $7 a-h$ Series of Scaffolds ${ }^{b}$

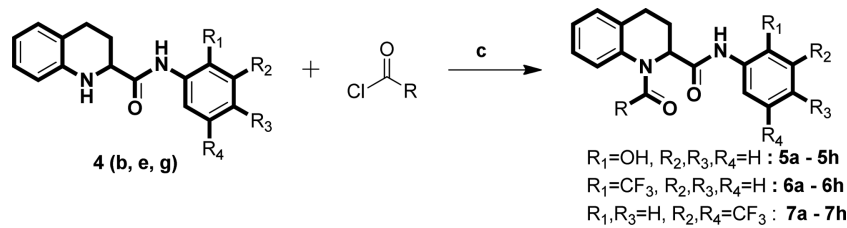

${ }^{b}$ Reagents and conditions: (c) triethylamine, anhydrous THF, $0{ }^{\circ} \mathrm{C}$, 5-10 min, RT, 30-60 min.
(CDI) in tetrahydrofuran at room temperature. This reaction afforded the $3 \mathbf{a}-\mathbf{g}$ series of $N$-(substituted)quinoline-2carboxamides in good yields (Scheme 1 ). The $\mathbf{3 a}-\mathbf{g}$ derivatives were also converted to $4 \mathrm{a}-\mathrm{g}$ by $\mathrm{Pd} / \mathrm{C}$ hydrogenation reaction $\left(\mathrm{H}_{2}\right.$ balloon) in ethanol solvent at room temperature. To obtain the $\mathbf{5 a}-\mathbf{h}, \mathbf{6} \mathbf{a}-\mathbf{h}$, and $7 \mathbf{a}-\mathbf{h}$ series, we performed acylation reaction in the presence of triethylamine in anhydrous tetrahydrofuran (Scheme 2). All newly synthesized derivatives $(3 a-g, 4 a-g, 5 a-h, 6 a-h$, and $7 a-h)$ were confirmed by ${ }^{1} \mathrm{H}$ and ${ }^{13} \mathrm{C}$ NMR and mass spectra. In evaluation studies of inhibition of LPS-induced NF- $\kappa$ B transcriptional activity, we compared all synthesized derivatives $(\mathbf{4 a}-\mathbf{g}, \mathbf{5 a}-\mathbf{h}, \mathbf{6 a}-\mathbf{h}$, and $\mathbf{7 a}-\mathbf{h})$ with the reference compound pyrrolidine dithiocarbamate (PDTC), which acts as an antioxidant and is a potent inhibitor of NF- $\kappa$ B activation, ${ }^{21-25}$ and also with the lead compound KL-1156, which is an inhibitor of NF- $\kappa \mathrm{B}$ translocation to the nucleus in LPS-stimulated RAW 264.7 macrophages. $^{26}$

Initially, we screened the $\mathbf{4} \mathbf{a}-\mathbf{g}$ derivatives; they exhibited marginal inhibitory effects on NF- $\kappa \mathrm{B}$ transcriptional activity (Table 1). After finding that the tetrahydroquinoline core motif was less potent, we next turned our attention mainly to the substitutions of $\mathrm{R}, \mathrm{R}_{1}, \mathrm{R}_{2}, \mathrm{R}_{3}$, and $\mathrm{R}_{4}$, which resulted in 24 derivatives $(\mathbf{5 a}-\mathbf{h}, \mathbf{6} \mathbf{a}-\mathbf{h}$, and $\mathbf{7 a}-\mathbf{h}$; Table 1$)$. Among them, 5e $\left(\mathrm{IC}_{50}: 1.4 \pm 0.71 \mu \mathrm{M}\right)$, 6f $\left(\mathrm{IC}_{50}: 0.90 \pm 0.071 \mu \mathrm{M}\right)$, $6 \mathrm{~g}\left(\mathrm{IC}_{50}: 0.70 \pm 0.071 \mu \mathrm{M}\right)$, and $6 \mathrm{~h}\left(\mathrm{IC}_{50}: 2.7 \pm 0.42 \mu \mathrm{M}\right)$ exhibited outstanding inhibitory effects (Figure 1) on LPSinduced NF- $\kappa \mathrm{B}$ transcriptional activity in comparison with remaining derivatives (Table 1). After having the initial experimental results, structure-activity relationship development was initiated for the tetrahydroquinoline scaffold. The 1,2,3,4-tetrahydroquinoline-2-carboxamide motif was modified at two key positions interpreted as $\mathrm{R}$, and substitutions were performed at the aromatic system $\left(\mathrm{R}_{1}, \mathrm{R}_{2}, \mathrm{R}_{3}\right.$, and $\left.\mathrm{R}_{4}\right)$. In the first set of compounds, we performed different substitutions at $R_{1}, R_{2}, R_{3}$, and $R_{4}$, which resulted in $4 \mathbf{a}-\mathbf{g}$ analogues. Subsequently $\mathrm{R}_{1}=\mathrm{R}_{2}=\mathrm{R}_{3}=\mathrm{R}_{4}=\mathrm{H}\left(4 \mathrm{a}, \mathrm{IC}_{50} 60 \mu \mathrm{M}\right)$ was

Table 1. Inhibitory Effect on LPS-Induced NF- $\kappa$ B Transcriptional Activity for 1,2,3,4-Tetrahydroquinolines

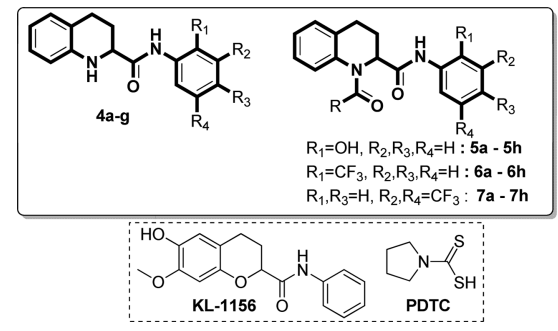

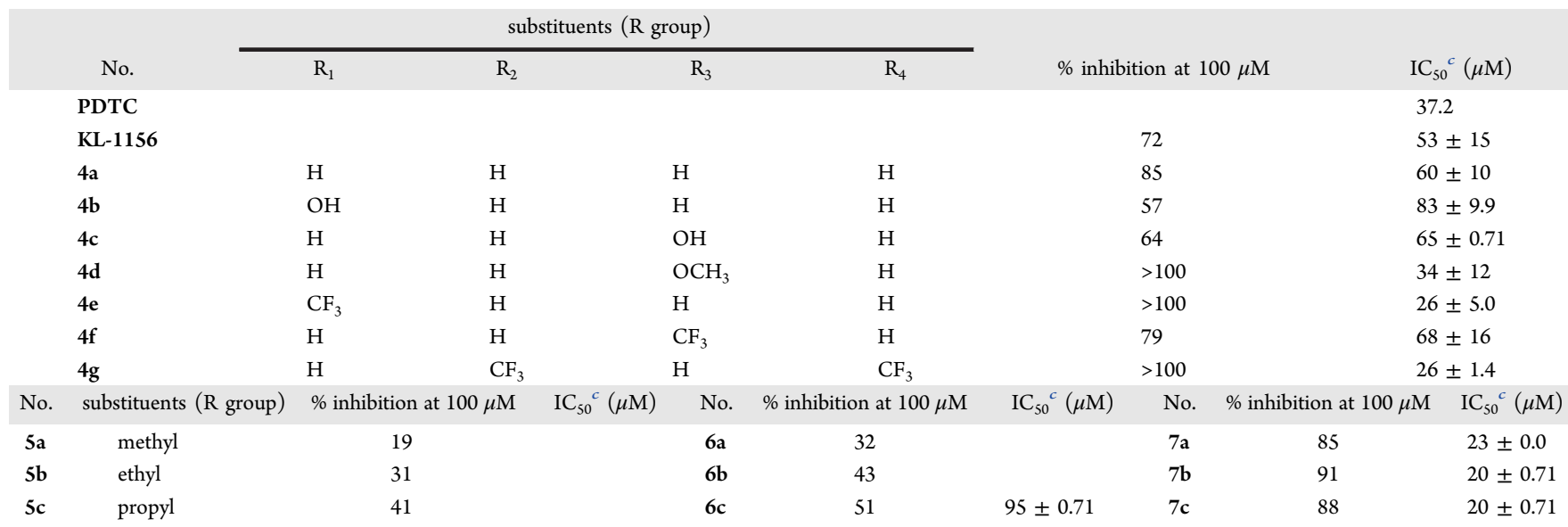


Table 1. continued

\begin{tabular}{|c|c|c|c|c|c|c|c|c|c|}
\hline No. & substituents ( $\mathrm{R}$ group) & $\%$ inhibition at $100 \mu \mathrm{M}$ & $\mathrm{IC}_{50}^{c}(\mu \mathrm{M})$ & No. & $\%$ inhibition at $100 \mu \mathrm{M}$ & $\mathrm{IC}_{50}{ }^{c}(\mu \mathrm{M})$ & No. & $\%$ inhibition at $100 \mu \mathrm{M}$ & $\mathrm{IC}_{50}{ }^{c}(\mu \mathrm{M})$ \\
\hline $5 d$ & octyl & 22 & & $6 d$ & 63 & $27 \pm 0.71$ & $7 \mathrm{~d}$ & 58 & $51 \pm 21$ \\
\hline $5 e$ & phenyl & $>100$ & $1.4 \pm 0.071$ & $6 e$ & 44 & & $7 e$ & 66 & $29 \pm 0.71$ \\
\hline $5 f$ & 2-chlorophenyl & 78 & $20 \pm 0.71$ & $6 f$ & 82 & $0.90 \pm 0.071$ & $7 \mathrm{f}$ & 90 & $23 \pm 0.0$ \\
\hline $5 g$ & 3-chlorophenyl & 58 & $78 \pm 2.1$ & $6 \mathrm{~g}$ & 90 & $0.70 \pm 0.071$ & $7 \mathrm{~g}$ & 68 & $27 \pm 0.71$ \\
\hline $5 \mathrm{~h}$ & 4-chlorophenyl & 82 & $20 \pm 2.8$ & $6 h$ & 92 & $2.7 \pm 0.42$ & $7 \mathbf{h}$ & 92 & $20 \pm 2.1$ \\
\hline
\end{tabular}

${ }^{c} \mathrm{IC}_{50}$ values are means of the concentration $(\mu \mathrm{M})$ exhibiting $50 \%$ inhibition of LPS-induced NF- $\kappa \mathrm{B}$ transcriptional activity.

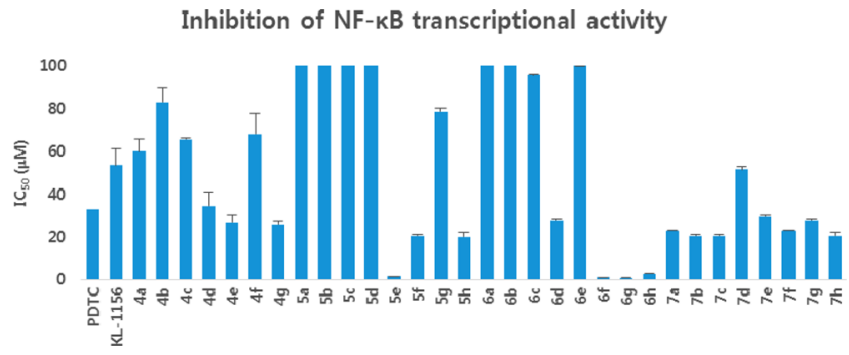

Figure 1. Efficacy of $4 a-g, 5 a-h, 6 a-h$, and $7 a-h$ analogues in inhibition of NF- $\kappa$ B transcriptional activities.

prepared to study the effect of the core 1,2,3,4-tetrahydroquinoline-2-carboxamide motif. We also examined the electronic influence of different groups at $\mathrm{R}_{1}, \mathrm{R}_{2}, \mathrm{R}_{3}$, and $\mathrm{R}_{4}$, including electron-deficient $\left(-\mathrm{CF}_{3}\right)$ and electron-rich groups $\left(-\mathrm{OCH}_{3}\right.$ and $-\mathrm{OH})$. Next, we introduced various acyl and aroyl groups at the 1-position of tetrahydroquinoline-2-carboxamides, which resulted in $\mathbf{5 a}-\mathbf{h}, \mathbf{6 a}-\mathbf{h}$, and $7 \mathbf{a}-\mathbf{h}$ analogues. Sizes of different aliphatic chains $(-\mathrm{R})$ and substituents at the aromatic ring were then examined. The inhibitory effects of these compounds $(4 a-g, 5 a-h, 6 a-h$, and $7 a-h)$ depended on the nature of the substitution at the R-position and the substituents $\left(R_{1}, R_{2}\right.$, $\mathrm{R}_{3}$, and $\mathrm{R}_{4}$ ) on the $\mathrm{N}$-phenyl ring of tetrahydroquinoline-2carboxamides. For instance, with $\mathrm{R}=$ an alkyl group (methyl, ethyl, propyl, or octyl), we did not notice any significant inhibitory effects, but with $\mathrm{R}=$ phenyl. The following compounds exhibited excellent inhibitory effects on LPS-induced NF- $\kappa \mathrm{B}$ transcriptional activity (Figure 2$): 5 e\left(\mathrm{IC}_{50}: 1.4 \pm 0.071 \mu \mathrm{M}\right.$, about 26 and 37 times more potent than PDTC and KL-1156, respectively), 6f ( $\mathrm{IC}_{50}: 0.90 \pm 0.071 \mu \mathrm{M}$, about 41 and 58 times more potent), $6 \mathrm{~g}\left(\mathrm{IC}_{50}: 0.70 \pm 0.071 \mu \mathrm{M}\right.$, about 53 and 75 times), and $6 \mathrm{~h}\left(\mathrm{IC}_{50}: 2.7 \pm 0.42 \mu \mathrm{M}\right.$, about 13 and 19 times). We also tested other substitutions at the R-position and different substituents at the $\mathrm{R}_{1}, \mathrm{R}_{2}, \mathrm{R}_{3}$, and $\mathrm{R}_{4}$ positions of the 1,2,3,4-tetrahydroquinoline core motif (Table 1). To explain the trend toward NF- $\kappa \mathrm{B}$ inhibition interestingly, the electron-withdrawing group $-\mathrm{CF}_{3}$ at the $\mathrm{R}_{1}$ position resulted in outstanding inhibitory effects on LPS-induced NF- $\kappa$ B transcriptional activity in comparison with any electron-releasing group (for example, $-\mathrm{OH}$ ). We also noticed that $-\mathrm{I}$ and $+\mathrm{M}$ effect groups (such as $-\mathrm{Cl}$ ) at the second and third positions of the aryl group of $\mathrm{R}$ in combination with $-\mathrm{CF}_{3}$ at the $\mathrm{R}_{1}$ position also showed excellent inhibition of NF- $\kappa \mathrm{B}$ transcriptional activity $(\mathbf{6 g}$, $\mathrm{IC}_{50}: 0.70 \pm 0.071 \mu \mathrm{M} ; 6$ ff, $\left.\mathrm{IC}_{50}: 0.90 \pm 0.071 \mu \mathrm{M}\right)$. Overall, most of the synthesized compounds $(4 \mathrm{~d}, 4 \mathrm{e}, 4 \mathrm{~g}, 5 \mathrm{f}, 5 \mathrm{~h}, 6 \mathrm{~d}, 7 \mathrm{a}-\mathrm{c}$, and $7 \mathbf{e}-\mathbf{h})$ were more potent inhibitors of NF- $\kappa \mathrm{B}$ transcriptional activity than PDTC and KL-1156 (Figure 2). We next studied the in vitro cytotoxicity of the synthesized compounds and initially evaluated quinoline-2-carboxamide derivatives $(3 \mathbf{a}-\mathbf{g})$ with the human lung cancer cell line (NCI-H23) and doxorubicin (ADR) as a reference compound.
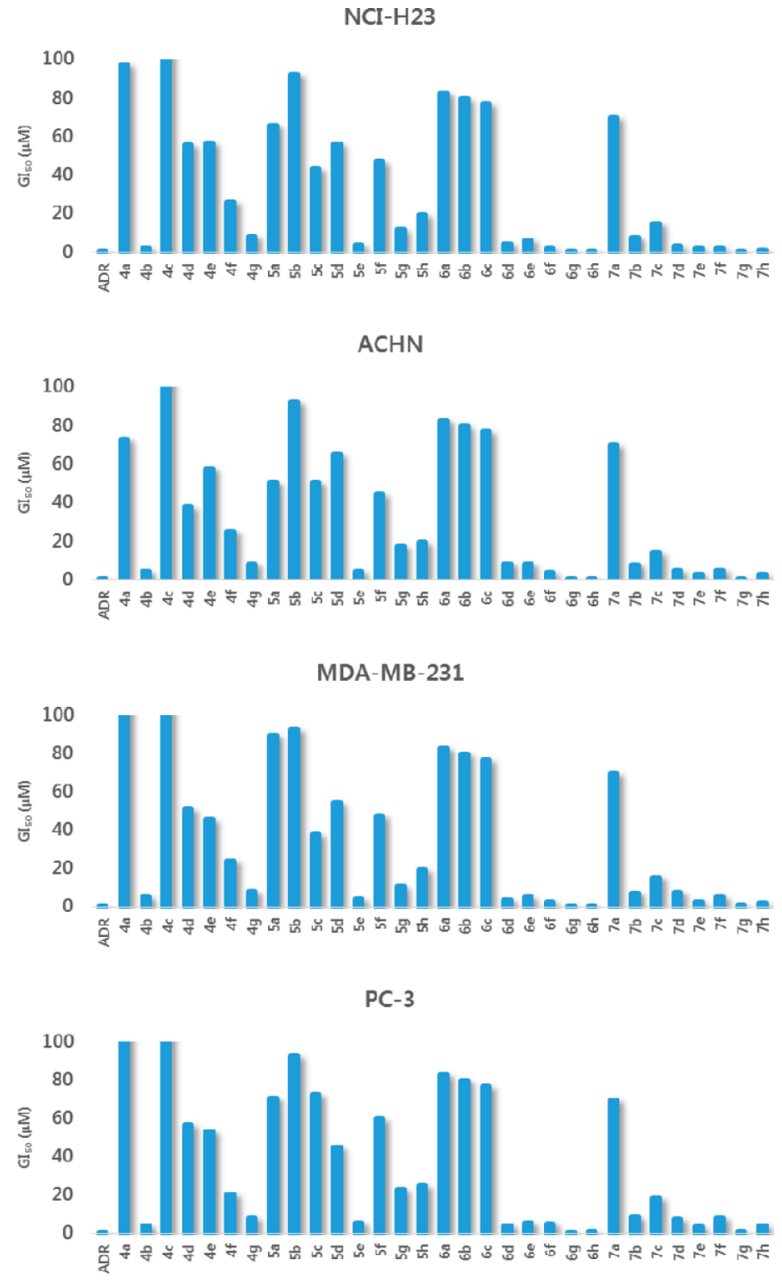

NUGC-3

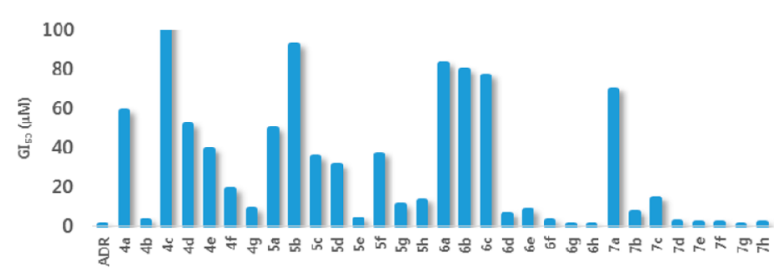

HCT 15

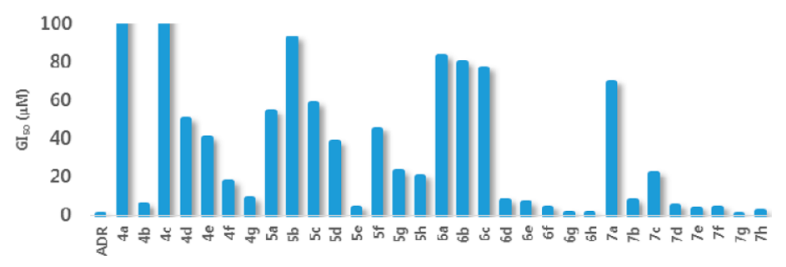

Figure 2. In vitro efficacy of $4 \mathbf{a}-\mathbf{g}, 5 \mathbf{a}-\mathbf{h}, \mathbf{6 a}-\mathbf{h}$, and $7 \mathbf{a}-\mathbf{h}$ analogues in inhibiting growth of human cancer cell lines. 
Table 2. Cytotoxicity of $3 a-g$ Series against Lung Cancer (NCI-H23) Cell Lines

\begin{tabular}{llllll} 
No. & $\mathrm{R}_{1}$ & $\mathrm{R}_{2}$ & \multicolumn{1}{c}{$\mathrm{R}_{3}$} & $\mathrm{R}_{4}$ & \multicolumn{1}{c}{$\mathrm{GI}_{50}(\mu \mathrm{M})^{d}$} \\
ADR & & & & & $0.101 \pm 0.00602$ \\
3a & $\mathrm{H}$ & $\mathrm{H}$ & $\mathrm{H}$ & $\mathrm{H}$ & $108 \pm 8.74$ \\
3b & $\mathrm{OH}$ & $\mathrm{H}$ & $\mathrm{H}$ & $\mathrm{H}$ & $87.5 \pm 9.77$ \\
3c & $\mathrm{H}$ & $\mathrm{H}$ & $\mathrm{OH}$ & $\mathrm{H}$ & $102 \pm 11.4$ \\
3d & $\mathrm{H}$ & $\mathrm{H}$ & $\mathrm{OCH}_{3}$ & $\mathrm{H}$ & $7.65 \pm 1.93$ \\
3e & $\mathrm{CF}_{3}$ & $\mathrm{H}$ & $\mathrm{H}$ & $\mathrm{H}$ & $>90$ \\
3f & $\mathrm{H}$ & $\mathrm{H}$ & $\mathrm{CF}_{3}$ & $\mathrm{H}$ & $>90$ \\
$3 \mathbf{3}$ & $\mathrm{H}$ & $\mathrm{CF}_{3}$ & $\mathrm{H}$ & $\mathrm{CF}_{3}$ & $1.44 \pm 0.463$
\end{tabular}

${ }^{d} \mathrm{GI}_{50}$ values are taken as a mean from three experiments and correspond to the agent's concentration causing a 50\% decrease in net cell growth.

As shown in Table 2, electron-withdrawing substituents such as $-\mathrm{CF}_{3}$ at the $\mathrm{R}_{2}$ and $\mathrm{R}_{4}$ positions of the phenyl ring $\left(3 \mathrm{~g}, \mathrm{GI}_{50}\right.$ $1.44 \pm 0.463 \mu \mathrm{M})$ resulted in the most potent cytotoxicity. The series $\mathbf{4 a}-\mathbf{g}, \mathbf{5 a}-\mathbf{h}, \mathbf{6 a}-\mathbf{h}$, and $7 \mathbf{a}-\mathbf{h}$ were also evaluated for in vitro cytotoxicity against six human cancer cells: NCI-H23, ACHN (renal), MDA-MB-231 (breast), PC-3 (prostate), NUGC-3 (gastric), and HCT15 (colon) (Table 3). Any substitution on the phenyl ring was not beneficial, and only $\mathbf{4 b}$ $\left(\mathrm{GI}_{50} 2.23 \pm 0.455 \mu \mathrm{M}\right)$ exhibited better cytotoxic activities against all tested cell lines than other analogues of the $4 \mathbf{a}-\mathbf{g}$ series (Table 3). To further confirm that the tetrahydroquinoline motif is beneficial for cytotoxicity, we executed acylation reaction with triethyl amine in tetrahydrofuran with $4 \mathbf{b}, 4 \mathbf{e}$, and $\mathbf{4 g}$; introduction of electron-rich or electron-withdrawing substituents at the $\mathrm{R}_{1}$ position afforded $\mathbf{5 a}-\mathbf{h}, \mathbf{6} \mathbf{a}-\mathbf{h}$, and $7 \mathbf{a}-\mathbf{h}$ analogues. As expected, these analogues had improved cytotoxicity against all tested cell lines (Figure 2), suggesting that substitutions at the $R_{1}$ position and the first position of the tetrahydroquinoline motif are most important (Table 3). Compound 5e exhibited the highest cytotoxicity (Table 3) against all evaluated cell lines $\left(\mathrm{NCI}-\mathrm{H} 23, \mathrm{GI}_{50} 3.49 \pm 0.999 \mu \mathrm{M}\right.$; NUGC-3, GI $I_{50} 3.78 \pm 0.618 \mu \mathrm{M} ; \mathrm{HCT} 15, \mathrm{GI}_{50} 3.83 \pm$ $0.994 \mu \mathrm{M})$. The importance of an electron-withdrawing group was also confirmed by $\mathbf{6 g}$ and $\mathbf{6 h}$ derivatives, which have $-\mathrm{CF}_{3}$ and $-\mathrm{Cl}$ on both phenyl rings and exhibited outstanding cytotoxicity $\left(6 \mathrm{~g}, \mathrm{GI}_{50} 0.292 \pm 0.111-0.797 \pm 0.173 \mu \mathrm{M} ; 6 \mathbf{6 h}\right.$, $\left.\mathrm{GI}_{50} 0.307 \pm 0.0 .0941-0.839 \pm 0.0610 \mu \mathrm{M}\right)$ against all tested cell lines (Figure 2, Table 3). The $-\mathrm{CF}_{3}$ group at the $\mathrm{R}_{2}$ and $\mathrm{R}_{4}$ positions of the phenyl ring in $7 \mathrm{~g}$ also resulted in potent cytotoxicity against all tested cell lines (0.420-1.19 $\mu \mathrm{M}$; Table 3). Compound $\mathbf{7 h}$ also exhibited potent cytotoxicity against lung $\left(\mathrm{NCI}-\mathrm{H} 23\left(\mathrm{GI}_{50} 0.889 \pm 0.102 \mu \mathrm{M}\right)\right.$ and gastric (NUGC-3, GI $\mathrm{G}_{50} 1.66 \pm 0.406 \mu \mathrm{M}$ ) cancer cell lines and moderate cytotoxicity against the other four cell lines (Table 3).

In summary, we identified a new class of 1,2,3,4tetrahydroquinolines as the most potent NF- $\kappa \mathrm{B}$ inhibitors and potent cytotoxic agents against human cancer cell lines.

The first round of screening starting from the initial lead scaffold $4 \mathrm{a}$ led to the discovery of $\mathbf{6 f}, \mathbf{6 g}$, and $6 \mathrm{~h}$ analogues. These new lead analogues inhibited LPS-induced NF- $\kappa$ B transcriptional activity 41, 53, and 13 times more potently, respectively, than the reference compound PDTC. Analogues 6f, $6 \mathrm{~g}$, and $\mathbf{6 h}$ have also shown the most potent in vitro cytotoxicity against all evaluated human cancer cell lines. Thus, 6f, $6 \mathrm{~g}, 6 \mathrm{~h}$, and related analogues provide new chemical tools for development of pathway-selective NF- $\kappa \mathrm{B}$ inhibitors with

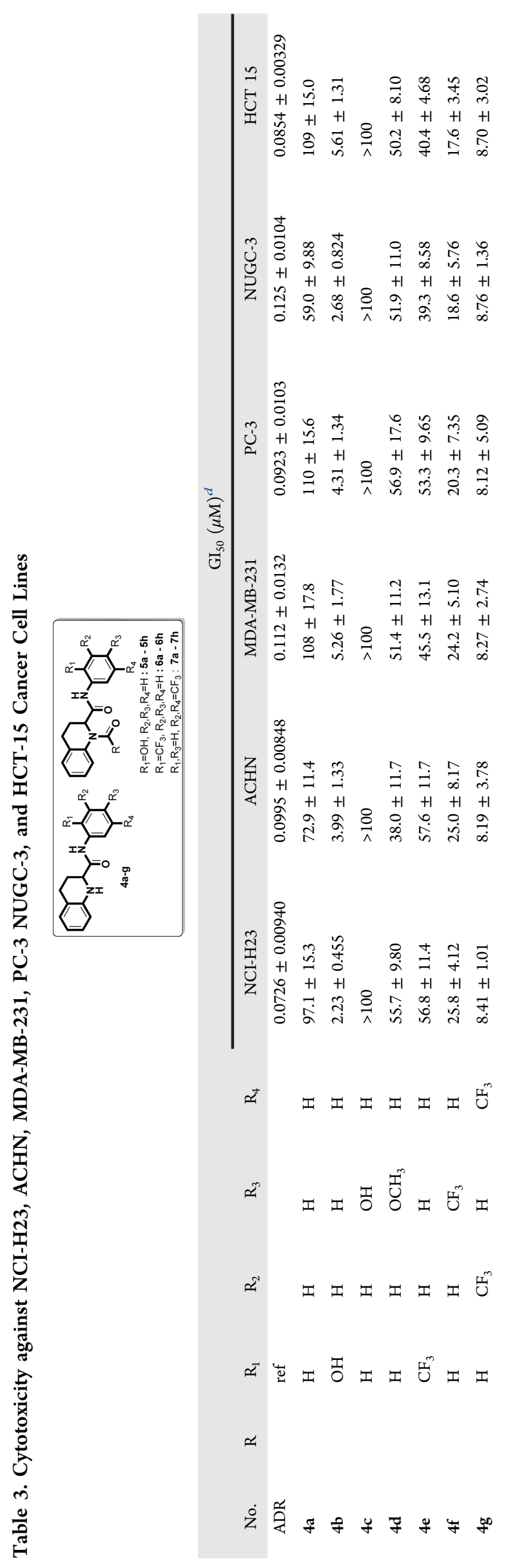

DOI: $10.1021 /$ acsmedchemlett.6b00004 ACS Med. Chem. Lett. 2016, 7, 385-390 


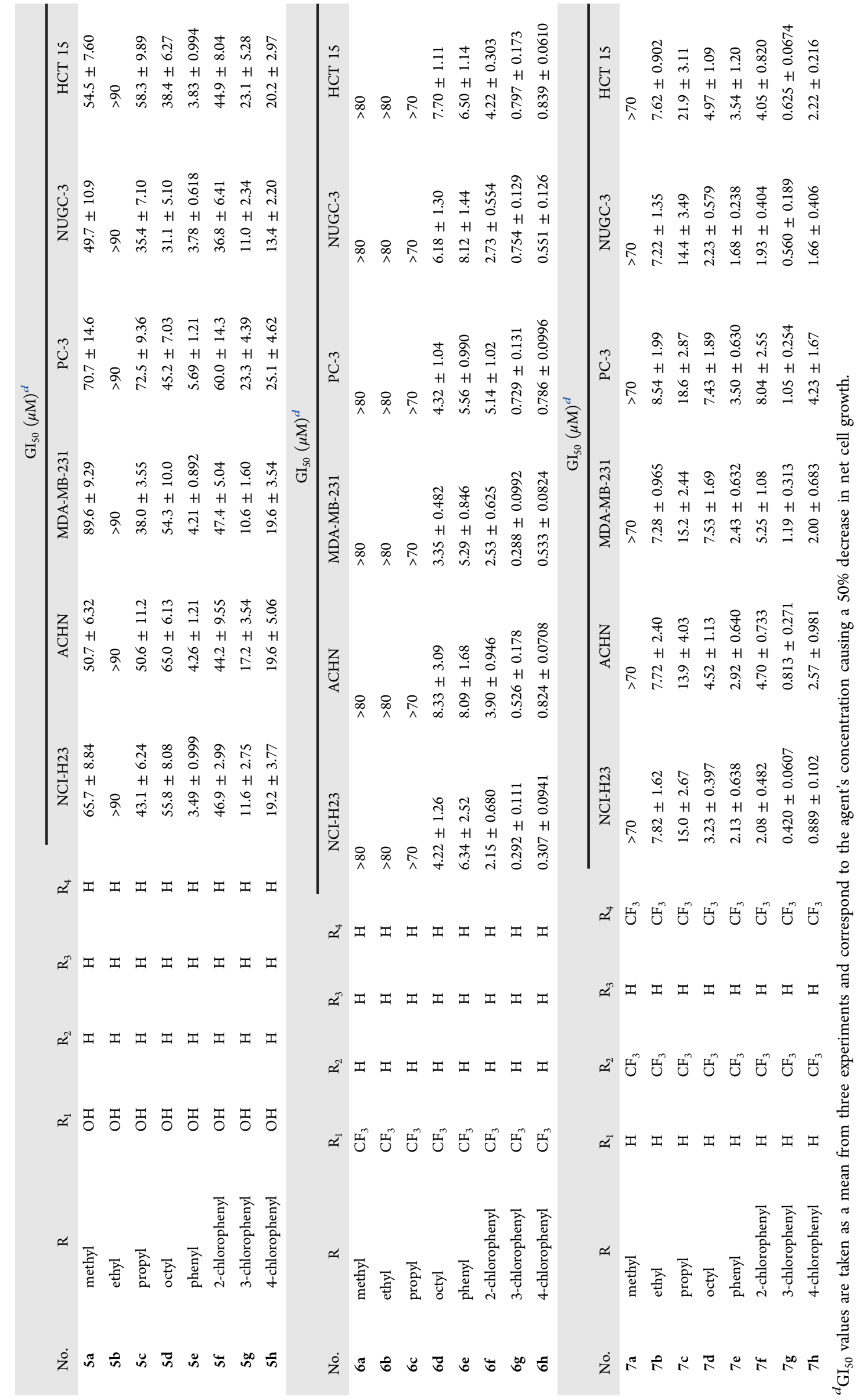


anticancer activity. Work on the enhancement of potency and pharmacological profiles of these probe molecules are underway.

\section{ASSOCIATED CONTENT}

\section{S Supporting Information}

The Supporting Information is available free of charge on the ACS Publications website at DOI: 10.1021/acsmedchemlett.6b00004.

Synthetic procedures, characterization of final products, biological assay protocols, and data and pharmacology profiles (PDF)

\section{AUTHOR INFORMATION}

\section{Corresponding Author}

*Tel: +82 43261 2811. Fax: +82 43268 2732. E-mail: medchem@chungbuk.ac.kr.

\section{Notes}

The authors declare no competing financial interest.

\section{ACKNOWLEDGMENTS}

This research was supported by Basic Science Research Program through the National Research Foundation of Korea (NRF) funded by the Ministry of Education, Science and Technology (NRF-2013R1A1A2009381), and Medical Research Center Program (2008-0062275).

\section{ABBREVIATIONS}

LPS, lipopolysaccharide; NF- $\kappa \mathrm{B}$, nuclear factor kappa-lightchain-enhancer of activated $\mathrm{B}$ cells

\section{REFERENCES}

(1) Sen, R.; Baltimore, D. Multiple nuclear factors interact with the immunoglobulin enhancer sequences. Cell 1986, 46, 705-716.

(2) Hayden, M. S.; Ghosh, S. NF- $\kappa$ B, the first quarter-century: Remarkable progress and outstanding questions. Genes Dev. 2012, 26, 203-234.

(3) Siebenlist, U.; Franzoso, G.; Brown, K. Structure, regulation and function of NF-кB. Annu. Rev. Cell Biol. 1994, 10, 405-455.

(4) Kumar, A.; Takada, Y.; Boriek, A. M.; Aggarwal, B. B. Nuclear factor- $\kappa \mathrm{B}$ : Its role in health and disease. J. Mol. Med. 2004, 82, 434448.

(5) Arepalli, S. K.; Choi, M.; Jung, J. K.; Lee, H. Novel NF- $\kappa$ B inhibitors: A patent review (2011-2014). Expert Opin. Ther. Pat. 2015, 25, 319-334.

(6) Kwak, J. H.; Jung, J. K.; Lee, H. Nuclear factor-kappa B inhibitors; A patent review (2006 - 2010). Expert Opin. Ther. Pat. 2011, 21, $1897-1910$.

(7) Srinivasan, B.; Johnson, T. E.; Lad, R.; Xing, C. Structure Activity relationship studies of chalcone leading to 3-hydroxy$4,3^{\prime}, 4^{\prime}, 5^{\prime}$-tetramethoxychalcone and its analogues as potent nuclear factor $\kappa \mathrm{B}$ inhibitors and their anticancer activities. J. Med. Chem. 2009, 52, 7228-7235.

(8) Chen, H.; Yang, Z.; Ding, C.; Chu, L.; Zhang, Y.; Terry, K.; Liu, H.; Shen, Q.; Zhou, J. Discovery of O-alkylamino-tethered niclosamide derivatives as potent and orally bioavailable anticancer agents. ACS Med. Chem. Lett. 2013, 4, 180-185.

(9) Choi, M.; Hwang, Y. S.; Kumar, A. S.; Jo, H.; Jeong, Y.; Oh, Y.; Lee, J.; Yun, J.; Kim, Y.; Han, S. B.; Jung, J. K.; Cho, J.; Lee, H. Design and synthesis of 3,4-dihydro-2H-benzo[h]chromene derivatives as potential NF- $\kappa$ B inhibitors. Bioorg. Med. Chem. Lett. 2014, 24, 24042407.

(10) Choi, M.; Jo, H.; Park, H. J.; Sateesh Kumar, A.; Lee, J.; Yun, J.; Kim, Y.; Han, S. B.; Jung, J. K.; Cho, J.; Lee, K.; Kwak, J. H.; Lee, H.
Design, synthesis, and biological evaluation of benzofuran- and 2,3dihydrobenzofuran-2-carboxylic acid $\mathrm{N}$-(substituted)phenylamide derivatives as anticancer agents and inhibitors of NF- $\kappa$ B. Bioorg. Med. Chem. Lett. 2015, 25, 2545-2549.

(11) Kwak, J. H.; Kim, Y.; Park, H.; Jang, J. Y.; Lee, K. K.; Yi, W.; Kwak, J. A.; Park, S. G.; Kim, H.; Lee, K.; Kang, J. S.; Han, S. B.; Hwang, B. Y.; Hong, J. T.; Jung, J. K.; Kim, Y.; Cho, J.; Lee, H. Structure-activity relationship of indoline-2-carboxylic acid $\mathrm{N}$ (substituted)phenylamide derivatives. Bioorg. Med. Chem. Lett. 2010, 20, 4620-4623.

(12) Sridharan, V.; Suryavanshi, P. A.; Menéndez, J. C. Advances in the chemistry of tetrahydroquinolines. Chem. Rev. 2011, 111, 71577259.

(13) Katritzky, A. R.; Rachwal, S.; Rachwal, B. Recent progress in the synthesis of 1,2,3,4-tetrahydroquinolines. Tetrahedron 1996, 52, 15031.

(14) Asolkar, K. N.; Schröder, D.; Heckman, R.; Lang, S.; WagnerDöbler, I.; Laatsch, H. Helquinoline, a new tetrahydroquinoline antibiotic from Janibacter limosus Hel 1. J. Antibiot. 2004, 57, 17-23.

(15) Pitta, M. G. R.; Pitta, M. G. R.; Rêgo, M. J. B. M.; Galdino, S. L. The evolution of drugs on schistosoma treatment: Looking to the past to improve the future. Mini-Rev. Med. Chem. 2013, 13, 493-508.

(16) Leeson, P. D.; Carling, R. W.; Moore, K. W.; Moseley, A. M.; Smith, J. D.; Stevenson, G.; Chan, T.; Baker, R.; Foster, A. C.; Grimwood, S.; Kemp, J. A.; Marshall, G. R.; Hoogsteen, K. 4-Amido-2carboxytetrahydroquinolines. Structure-activity relationships for antagonism at the glycine site of the NMDA receptor. J. Med. Chem. 1992, 35, 1954-1968.

(17) Khan, P. M.; Correa, R. G.; Divlianska, D. B.; Peddibhotla, S.; Sessions, E. H.; Magnuson, G.; Brown, B.; Suyama, E.; Yuan, H.; Mangravita-Novo, A.; Vicchiarelli, M.; Su, Y.; Vasile, S.; Smith, L. H.; Diaz, P. W.; Reed, J. C.; Roth, G. P. 2011. Identification of inhibitors of NOD1-induced nuclear factor- $\kappa \mathrm{B}$ activation. ACS Med. Chem. Lett. 2011, 2, 780-785.

(18) Bedoya, L. M.; Abad, M. J.; Calonge, E.; Saavedra, L. A.; Gutierrez C, M.; Kouznetsov, V. V.; Alcami, J.; Bermejo, P. 2010. Quinoline-based compounds as modulators of HIV transcription through NF- $\kappa$ B and Sp1 inhibition. Antiviral Res. 2010, 87, 338-344.

(19) Moon, K. Y.; Hahn, B. S.; Lee, J.; Kim, Y. S. A cell-based assay system for monitoring NF- $\kappa \mathrm{B}$ activity in human $\mathrm{HaCaT}$ transfectant cells. Anal. Biochem. 2001, 292, 17-21.

(20) Greten, F. R.; Eckmann, L.; Greten, T. F.; Park, J. M.; Li, Z. W.; Egan, L. J.; Kagnoff, M. F.; Karin, M. IKK $\beta$ links inflammation and tumorigenesis in a mouse model of colitis-associated cancer. Cell 2004, $118,285-296$.

(21) Nurmi, A.; et al. Pyrrolidine dithiocarbamate inhibits translocation of nuclear factor kappa-B in neurons and protects against brain ischaemia with a wide therapeutic time window. J. Neurochem. 2004, 91, 755-765.

(22) Hayakawa, M.; Miyashita, H.; Sakamoto, I.; Kitagawa, M.; Tanaka, H.; Yasuda, H.; Karin, M.; Kikugawa, K. Evidence that reactive oxygen species do not mediate NF- $\kappa \mathrm{B}$ activation. EMBO J. 2003, 22, $3356-3366$.

(23) Liu, S. F.; Ye, X.; Malik, A. B. In Vivo Inhibition of Nuclear Factor- $\kappa$ B Activation Prevents Inducible Nitric Oxide Synthase Expression and Systemic Hypotension in a Rat Model of Septic Shock. J. Immunol. 1997, 159, 3976-3983.

(24) Ziegler-Heitbrock, H. W. L.; Sternsdorf, T.; Liese, J.; Belohradsky, B.; Weber, C.; Wedel, A.; Schreck, R.; Bäuerle, P.; Ströbel, M. Pyrrolidine dithiocarbamate inhibits NF- $\kappa$ B mobilization and TNF production in human monocytes. J. Immunol. 1993, 151, 6986-6993.

(25) Schreck, R.; Meier, B.; Männel, D. N.; Dröge, W.; Baeuerle, P. A. Dithiocarbamates as potent inhibitors of nuclear factor $\kappa \mathrm{B}$ activation in intact cells. J. Exp. Med. 1992, 175, 1181-1194.

(26) Kim, B. H.; Reddy, A. M.; Lee, K. H.; Chung, E. Y.; Cho, S. M.; Lee, H.; Min, K. R.; Kim, Y. Inhibitory mechanism of chroman compound on LPS-induced nitric oxide production and nuclear factor$\kappa \mathrm{B}$ activation. Biochem. Biophys. Res. Commun. 2004, 325, 223-228. 